\title{
Fermentation Optimization, Fungistatic Effects and Tomato Growth Promotion of Four Biocontrol Bacterial Strains
}

\author{
Yao Zhang ${ }^{1}$, Xingyuan Wang ${ }^{1}$, Sibo Liang ${ }^{2}$, Yuying Shi ${ }^{2}$, Xiuling Chen ${ }^{2}$, Jiayin Liu ${ }^{1}$ and Aoxue Wang ${ }^{1,2, *(D)}$ \\ 1 College of Life Sciences, Northeast Agricultural University, Harbin 150030, China; \\ zy13263696020@163.com (Y.Z.); wxy18246718896@163.com (X.W.); 13100956039@163.com (S.L.); \\ 13040216@163.com (J.L.) \\ 2 College of Horticulture and Landscape Architecture, Northeast Agricultural University, \\ Harbin 150030, China; yuyingshi123456@163.com (Y.S.); chenx@neau.edu.cn (X.C.) \\ * Correspondence: axwang@neau.edu.cn
}

Citation: Zhang, Y.; Wang, X.; Liang, S.; Shi, Y.; Chen, X.; Liu, J.; Wang, A. Fermentation Optimization, Fungistatic Effects and Tomato Growth Promotion of Four Biocontrol Bacterial Strains. Agriculture 2021, 11, 686. https://doi.org/10.3390/ agriculture11070686

Academic Editor: Francesco Vinale

Received: 17 May 2021

Accepted: 14 July 2021

Published: 20 July 2021

Publisher's Note: MDPI stays neutral with regard to jurisdictional claims in published maps and institutional affiliations.

Copyright: (c) 2021 by the authors. Licensee MDPI, Basel, Switzerland. This article is an open access article distributed under the terms and conditions of the Creative Commons Attribution (CC BY) license (https:// creativecommons.org/licenses/by/ $4.0 /)$.

\begin{abstract}
Tomato is a widely cultivated crop that is important for its nutritional value and genetic diversity. Tomato production is seriously challenged by pests and diseases, among which tomato gray mold and leaf mold are particularly serious. Biological control is one of the most preferred methods for disease management in tomato production. At present, the fungi used to control tomato gray mold are mainly Trichoderma and yeast. Bacillus and actinomycetes are the most effective microorganisms for controlling tomato leaf mold. Tomato gray mold and leaf mold often occur at the same time during the production process, yet there are fewer strains for controlling both diseases at the same time. Biocontrol bacteria Pseudomonas azotoformans WXCDD51, Bacillus sp. WXCDD105, Bacillus subtilis BS and Bacillus amyloliquefaciens BS WY-1, which were isolated and screened in the previous stage, can prevent both tomato gray mold and leaf mold. Here, we optimized liquid fermentation for the four biocontrol bacterial strains together. We obtained the best fermentation medium formula and fermentation conditions for the four biocontrol bacteria. The broad-spectrum properties of the four biocontrol bacteria were tested, and, on this basis, compound strains were constructed. The control effect of single and compound strains on tomato gray mold and leaf mold was evaluated. Their potential effects on the growth of tomato seeds and seedlings were also studied. This research provides a foundation for the development and use of compound bacteria for growth promotion and disease management in tomato production.
\end{abstract}

Keywords: tomato gray mold; tomato leaf mold; biocontrol bacteria; liquid fermentation; growth promotion

\section{Introduction}

Gray mold and leaf mold are prevalent in tomato production, leading to huge economic losses [1-3]. They were originally controlled with chemical pesticides; however, this control method is not sustainable due to the high cost of synthetic pesticides and their long-term effect on the environment. Microbial pesticides, on the other hand, are more sustainable. Therefore, the application of beneficial microorganisms to control tomato diseases has become increasingly popular.

Botrytis cinerea (teleomorph: Botryotinia fuckeliana) is an airborne plant pathogen with a necrotrophic lifestyle, attacking over 200 crop hosts worldwide [4]. It causes the gray mold disease in tomato and can damage many parts of the crop plant, leading to easily identifiable symptoms. Infection damages the quality and taste of the tomato fruit, resulting in significant economic loss [5]. The pathogen has a complex life cycle and can be spread by spores, hyphae and sclerotia. Fulvia fulva is the causal organism of tomato leaf mold [6], mainly infecting the leaves and fruits, thus leading to significant yield and quality losses [7]. The pathogen invades plants by means of air and water currents. Crop plants are prone to disease during the flowering period and have a higher incidence during the fruit ripening 
period. Low temperature and high humidity, weak host growth, low ventilation, high planting density, continuous rainy weather and repeated cropping are all likely to induce these two diseases [8].

Biological control is the use of biological control agents (BCAs) to prevent and control crop diseases caused by bacteria, fungi and nematodes [9]. In recent years, there have been many reports on the use of biological control to mitigate tomato gray mold and leaf mold. At present, the fungi used to control tomato gray mold are mainly Trichoderma and yeast, and the bacteria are mainly Bacillus, Pseudomonas and Photobacterium [10-14]. Bacillus and actinomycetes are the most effective microorganisms for controlling tomato leaf mold [15-17].

In recent years, bio-fermentation engineering has been optimized in agriculture for the fermentation of bacteria metabolites to increase crop production and prevent diseases. It includes two aspects: one is the optimization of the medium composition, and the other is the optimization of the fermentation conditions. Using suitable optimization methods can reduce production costs while improving production efficiency, making it more applicable. There are many factors that affect the fermentation process of microorganisms [18-20]. Some experimental techniques and design methods have been widely used to optimize both the medium composition and culture conditions [21-23]. Research has shown that compound biocontrol bacteria are able to control plant diseases and promote plant growth The combination of bacteria, or the combination of bacteria and fungi, to form a composite inoculant can prevent and control tomato gray mold, but compound strains for preventing leaf mold have not been reported thus far [24]. Using Bacillus subtilis M6 and Trichoderma 10 to prepare 800 times and 1000 times compound bacteria dilutions can replace chemical agents in controlling tomato gray mold [25]. Based on degrading bacteria and biocontrol bacteria from Bacillus, the four groups of Z1, Z2, Z3 and Z4 composite strains constructed by the researchers have good comprehensive effects and can promote tomato growth and increase yield. The control effect of tomato gray mold is over $80 \%$. The combination of strains with different mechanisms of action can improve the control effect. This may be related to the changes in nutritional conditions after the combination of biocontrol bacteria [26], the interaction between strains [27] and the activation of related genes of the strains [28].

In this study, biocontrol bacteria Pseudomonas azotoformans WXCDD51, Bacillus sp. WXCDD105, Bacillus subtilis BS and Bacillus amyloliquefaciens BS WY-1 were used as materials to optimize the liquid fermentation process, and their spectrum of disease control was tested. Based on this, the compound combinations were tested for their promotion of tomato growth and their biocontrol effects on gray mold and leaf mold. This study provides a theoretical and technological foundation for the development and use of compound bacteria in tomato production.

\section{Materials and Methods}

\subsection{Bacterial Strains and Plant Material}

The bacteria Pseudomonas azotoformans WXCDD51, Bacillus sp. WXCDD105, Bacillus subtilis BS and Bacillus amyloliquefaciens BS wy-1, which have a control effect on tomato gray mold, were isolated and preserved in our laboratory. The tomato cv. Dongnong 713 was provided by the Tomato Research Institute of Northeast Agricultural University in China. Tomato variety 'Dongnong 713' is a variety researched and preserved in our laboratory. We conducted a pathogenicity test and found that it was susceptible to the pathogens. It has no resistance to Botrytis cinerea and Cladosporium fulvum Cooke. LB (Luria-Bertani) medium (5 g yeast extract, $10 \mathrm{~g}$ peptone, $10 \mathrm{~g} \mathrm{NaCl}, 15-20 \mathrm{~g}$ agarose, $1000 \mathrm{~mL}$ distilled water, $\mathrm{pH} 7$ ) and PDA (Potato Dextrose Agar) medium (20 g glucose, $200 \mathrm{~g}$ potato, agar 15-20 g, $1000 \mathrm{~mL}$ distilled water, $\mathrm{pH}$ 7) were used. 


\subsection{Research on Liquid Fermentation Technology of Four Biocontrol Bacteria}

\subsubsection{Strain Culture}

The four biocontrol bacteria, which were stored at $4{ }^{\circ} \mathrm{C}$, were cultured, and single colonies based on colony morphology, color and size were transferred into LB solid medium for purification by the plate streak method and cultivated at $30^{\circ} \mathrm{C}$ for $24 \mathrm{~h}$. A single colony was picked the next day, transferred to $5 \mathrm{~mL}$ LB liquid medium, $30^{\circ} \mathrm{C}$, and cultured for $18 \mathrm{~h}$ at $200 \mathrm{rpm}$ shaking. The seed liquid was transferred into $50 \mathrm{~mL}$ liquid medium $2 \%(v / v)$, cultured with shaking at $30^{\circ} \mathrm{C}$ and $200 \mathrm{rpm} / \mathrm{min}$ for $24 \mathrm{~h}$ and used in the study on fermentation conditions. The seed solution was diluted to 5 concentrations in a 3-fold dilution gradient, and the number of viable bacteria in each dilution was determined by the plate colony counting method, while the OD600 value was determined by a spectrophotometer. LB culture broth of the same dilution was used as the blank control, and the number of viable bacteria in the fermentation broth was used as the ordinate, while absorbance was used as the abscissa to establish a standard curve.

\subsubsection{Screening of Initial Fermentation Medium}

LB, PPM, NYD and KB (LB: Luria-Bertani; PPM: Plant Preservative Mixture) culture broth was used as the initial fermentation medium, the bacteria broth was fermented and measured and the number of viable bacteria was calculated. After shaking for 4-7 days, the antibacterial activity of the sterile fermentation filtrate was measured. Water was used as control, and the experiment was repeated 3 times. We used the Oxford cup method to determine the antibacterial activity of each sterile fermentation filtrate. After the pathogens were cultured on the plate, the pathogen cake $(\Phi=8 \mathrm{~mm})$ was placed in the center of the PDA plate $(\Phi=90 \mathrm{~mm})$. We placed the Oxford cup at $25 \mathrm{~mm}$ equidistant in three directions from the center point and added $100 \mu \mathrm{L}$ sterile filtrate. We incubated this in a $27^{\circ} \mathrm{C}$ constant temperature incubator for 7 days and measured the inhibition distance [29].

\subsubsection{Optimization of Fermentation Medium Composition}

A single factor test was used to screen out the main components of the fermentation medium of the four biocontrol bacteria. The orthogonal test method was used to study the utilization of carbon, nitrogen and inorganic salts by the four biocontrol bacteria [30]. We screened out the optimal content of each factor according to the influence of various factors on the growth of biocontrol bacteria and the antibacterial activity of sterile fermentation broth at different levels. The initial fermentation conditions were as follows: inoculum volume $2 \%, 50 \mathrm{~mL}$ culture solution in a $250 \mathrm{~mL}$ Erlenmeyer flask, at $30^{\circ} \mathrm{C}, 200 \mathrm{rpm} / \mathrm{min}$ shaking. After $48 \mathrm{~h}$, the $\mathrm{OD}_{600}$ value was determined, while the antibacterial activity of the sterile fermentation filtrate was determined 2-7 days later (Tables S1 and S2).

\subsubsection{Optimization of Fermentation Conditions}

We used single factor experiments to determine the effects of the culture temperature, initial $\mathrm{pH}$, inoculum volume and liquid volume on the growth of each biocontrol bacterium and the production of antibacterial substances. The effect of different temperatures $\left(20^{\circ} \mathrm{C}\right.$, $25^{\circ} \mathrm{C}, 30^{\circ} \mathrm{C}$ and $37^{\circ} \mathrm{C}$ ) on the growth of the 4 bacterial strains was investigated by seeding $10 \mathrm{~mL}, 30 \mathrm{~mL}, 50 \mathrm{~mL}, 70 \mathrm{~mL}, 100 \mathrm{~mL}$ and $120 \mathrm{~mL}$ into $250 \mathrm{~mL}$ culture media at $1 \%, 2 \%, 3 \%$, $4 \%$ and $5 \%$ inoculum, in triplicates, incubated for $48 \mathrm{~h}$, and the absorbance was recorded at OD600. Additionally, eleven $\mathrm{pH}$ levels $(3,4,5,6,6.5,7.0,7.5,8.0,8.5,9.0$ and 10.0) were evaluated.

\subsection{Single and Compound Biocontrol Strains Promote the Growth of Tomato Seeds and Seedlings}

Two of the four biocontrol bacteria were placed in one group, and a total of six groups were created. A single colony of each strain was picked, inoculated in LB solid medium according to the vertical cross streaking method and cultivated at $30^{\circ} \mathrm{C}$ for $24 \mathrm{~h}$. Bacteria growth at the intersection was observed, and the experiment was repeated 3 times [30]. 


\subsubsection{Effect of Compound Bacteria Liquid on the Germination of Tomato Seeds}

We adjusted the concentration of the four biocontrol bacteria (WXCDD51, WXCDD105, $\mathrm{Ba}$, Bs wy-1) fermentation broths with sterile water to maintain the same concentration, and then we mixed them in equal amounts according to the three combinations of two, three and four strains, adjusting the final concentration to make each combination fermentation broth consistent $\left(10^{8} \mathrm{cfu} / \mathrm{mL}\right)$. After the tomato seeds were disinfected, we put 200 tomato seeds in a test tube containing $10 \mathrm{~mL}$ of each single and compound bacterial solution and sterile water. We soaked them at room temperature for $3 \mathrm{~h}$ and then took them out and put them in a sterile Petri dish, 50 tablets per dish. We added $3 \mathrm{~mL}$ of sterile water, incubated this at $28^{\circ} \mathrm{C}$ and added sterile water regularly and quantitatively. We calculated the germination rate $(2-5 \mathrm{~d})$ and recorded the radicle length of germinated tomato seeds, repeating this 3 times.

2.3.2. Effect of Single and Compound Bacteria Liquid on the Growth of Tomato Seedlings

Firstly, the effects of different concentrations and different treatment methods on tomato seedlings of each bacterial solution were measured, and then the growth-promoting effects of each single and compound bacterial solution on tomato seedlings were compared.

Two different concentrations: each an original bacterial solution $\left(10^{8} \mathrm{cfu} / \mathrm{mL}\right)$, were diluted 10 times and 100 times. This was applied by mixing soil, and water was used as a control.

There were three processing methods: Seed soaking: After soaking tomato seeds with the best dilution of the multiple-bacteria solution for $3 \mathrm{~h}$, they were sown and transplanted into a nutrient bowl at the 2 leaves and 1 heart stage. Seeds soaked in sterile water were used as control. Root irrigation: Seedlings at the 2 leaves and 1 heart stage were irrigated in bacterial solution, $20 \mathrm{~mL}$ per bowl, while sterile water was used as the control. Mixing soil: After taking 2 leaves and 1 core, the seedlings were transplanted into nutrient bowls. Each bowl was filled with an equal amount of nutrient soil mixed with $20 \mathrm{~mL}$ of the best dilution ratio of the bacteria solution. Aseptic water mixing soil treatment was used as a control. After each treatment was completed, it was placed in the greenhouse for routine management. At the 4-5 leaf stage, the morphological indicators were determined, 20 seedlings per treatment, 3 repetitions.

\subsection{Control Effect of Single and Compound Biocontrol Strains on Tomato Gray Mold and Leaf Mold}

Using tomato gray mold and leaf mold as indicator bacteria, the plate confrontation method was used to determine the antagonistic effects of the different compound bacterial solutions on tomato gray mold and leaf mold. Single bacteria and sterile water were used as control, repeated 3 times, and the rate of inhibition was calculated. Combinations of strains with strong antagonistic effects on tomato gray mold and leaf mold based on different compound ratios $(1: 1 ; 1: 2 ; 2: 1 ; 1: 3 ; 3: 1 ; 1: 4 ; 4: 1)$ were optimized. Single strains and sterile water were used as a control and repeated to determine the antibacterial activity.

2.4.1. Indoor In Vitro Control Effect of the Best Compound Biocontrol Strains against Tomato Gray Mold and Leaf Mold

In Vitro Control Effect on Fruit

Tomato fruits with the same size and maturity were selected and disinfected with $75 \%$ alcohol. The same concentrations $\left(10^{8} \mathrm{cfu} / \mathrm{mL}\right)$ of the compound bacterial solutions B-1 and B-2, and single strains Ba, Bs wy-1 and WXCDD105 were sprayed on fruits under aseptic conditions. After drying, the peel was pierced with an inoculation needle and inoculated with the gray mold hyphae. A sterile culture flask was used for cultivation at $25^{\circ} \mathrm{C}$, and the disease was observed daily. The vernier caliper cross method was used to measure the mycelial area, and the incidence, disease index and control effect were subsequently calculated. 


\section{Control Effect on Detached Leaves}

Young tomato leaves of the same size were selected and disinfected with $75 \%$ alcohol. The petioles were wrapped with moist cotton, placed in a Petri dish and covered with sterile filter paper. The spraying method refers to the control effect of isolated fruits. Then, we measured the chlorosis area, and calculated the incidence of detached leaves, disease index and control effect.

2.4.2. Greenhouse Control Effect of Single and Optimal Compound Biocontrol Strains on Tomato Gray Mold and Leaf Mold

Tomato seeds were sterilized, germinated and sown in growth medium consisting of pastoral soil and peat in a ratio of 3:1, and an appropriate amount of perlite was added. Tomato seedlings at the 2 leaves and 1 heart stage were transferred. Inoculation was conducted after the emergence of 4-5 true leaves. For a detailed description of the experimental method, refer to Wang et al., 2021.

\subsection{Antibacterial Substances Produced by Biocontrol Bacteria WXCDD51 and WXCDD105}

\subsubsection{Detection of the Ability of Strains to Secrete Extracellular Enzymes, Siderophores} and HCN

Protease, cellulase, chitinase, glucanase and ferritin identification media were used to specifically detect whether the strain has these enzyme activities. We placed an Oxford cup in the center of each specific medium and added $50 \mu \mathrm{L}$ of bacterial solution dropwise. It was incubated for $2-7 \mathrm{~d}$ at $30^{\circ} \mathrm{C}$, and we observed whether there was an enzymolysis circle.

\subsubsection{Determination of Antibacterial Crude Protein}

Fungicide crude protein was extracted by the ammonium sulfate fractional precipitation method. The saturation of ammonium sulfate was set to 30\%,50\%, 70\% and 90\%. After the crude product was obtained, the Oxford cup method was used, with tomato Botrytis cinerea as the indicator. We took the pathogenic bacteria cake $(\Phi=8 \mathrm{~mm})$ and placed it in the center of the PDA plate. We placed the Oxford cup on the four corners at equal distances around the pathogen. A $50 \mu \mathrm{L}$ sample was dropped into the Oxford cup, sterile water was used as blank control, cultured at $27^{\circ} \mathrm{C}$ for 7 days, and the antibacterial activity of crude protein was determined.

\subsubsection{Determination of Lipopeptide Antibiotics}

We used the hydrochloric acid precipitation method for the determination of lipopeptide antibiotics. The Oxford cup method was used to determine the antibacterial activity of lipopeptide antibiotics against Botrytis cinerea (the method is the same as Section 2.5.2).

\section{Results}

\subsection{Identification of the Best Fermentation Conditions for Four Biocontrol Bacteria}

The morphological, physiological and biological characteristics of the biocontrol bacterium WXCDD51, as well as analysis of its $16 \mathrm{~s}$ rDNA, revealed that this strain belongs to the genus Pseudomonas. The strain WXCDD105 was previously identified as Bacillus subtilis suBap.subtilis (Figures S1 and S2).

The general trend in the growth curve of all four biocontrol bacteria was an "S" curve, that is, the bacteria amount increased with an increase in the cultivation time. The end of logarithmic growth was at 18-30 h; therefore, $18 \mathrm{~h}$ was selected as this the best inoculation age, while the bacteria count reached a maximum at $48 \mathrm{~h}$ (Figure S3). The bacterial counts of the four biocontrol bacteria have a good linear relationship with the measured $\mathrm{OD}_{600}$ value. The greater the number of bacteria, the greater the $\mathrm{OD}_{600}$ value (Figure S4). We screened the initial fermentation medium of four strains of bacteria and combined the number of bacteria and antibacterial activity. The final strains WXCDD51 and Bs wy-1 were selected on NYD medium, and WXCDD105 and Ba were selected on KB medium (Figure S5). 
We optimized the composition of the fermentation medium and determined the optimal carbon source of the four strains. The results show that WXCDD51 uses sucrose as the carbon source to achieve the largest bacterial population, followed by potato starch and glycerin. Considering the cost of fermentation materials, potato starch was selected as the most suitable carbon source for WXCDD51 (Figure S6). Based on the two indicators of the bacterial count and antibacterial activity, sucrose, soluble starch and glycerol were selected as the optimal carbon sources for WXCDD105, Ba and Bs wy-1, respectively (Figure S6). In addition to the identification of the optimum carbon source for all four bacteria, the optimum nitrogen source of the four strains was also determined. Using the two indicators of bacterial mass and antibacterial activity, yeast powder was selected as the optimal nitrogen source for WXCDD51 and WXCDD105, while peanut meal powder was optimal for Ba and Bs wy-1 (Figure S7). WXCDD51 had its highest bacterial count for the first four combinations of inorganic salts: $\mathrm{Na}_{2} \mathrm{HPO}_{4}, \mathrm{KH}_{2} \mathrm{PO}_{4}, \mathrm{NaCl}$ and $\mathrm{MgSO}_{4}$. WXCDD105 had its highest bacterial count and antibacterial activity with the combination of $\mathrm{KH}_{2} \mathrm{PO}_{4}$, $\mathrm{CaCl}_{2}$ and $\mathrm{MnSO}_{4}$. Ba and $\mathrm{Bs} w y-1$ produced their highest bacteria count and antibacterial activity with the combination of $\mathrm{CaCl}_{2}, \mathrm{Na}_{2} \mathrm{HPO}_{4}$ and $\mathrm{KH}_{2} \mathrm{PO}_{4}$ (Figure S8).

Next, we optimized the fermentation conditions, and the effect of the temperature on bacterial growth was detected. When strain WXCDD51 was cultured at $30{ }^{\circ} \mathrm{C}$, and WXCDD105, Ba and Bs wy-1 were cultured at $37^{\circ} \mathrm{C}$, the cell density and the diameter of the inhibition zone of the fermentation broth both reached their maximum. Therefore, $30{ }^{\circ} \mathrm{C}$ was chosen as the optimum culture temperature for strain WXCDD51, and $37{ }^{\circ} \mathrm{C}$ as the optimum culture temperature for strains WXCDD105, Ba and Bs wy-1 (Figure S9). Based on the growth of the strains, we chose the starting $\mathrm{pH}$ of the fermentation medium to be WXCDD51: 7.0, WXCDD105: 6.5, Ba: 6.5 and Bs wy-1: 7.0 (Figure S10). When the inoculum amount was $2 \%$ and $3 \%$, the bacteria amount of the four biocontrol bacteria and the antibacterial activity of the fermentation broth were higher. Therefore, $2 \%$ of strains WXCDD51, WXCDD105 and Bs wy-1 was selected as the optimal inoculation amount, and $3 \%$ for strain $\mathrm{Ba}$ (Figure S11). The influence of the filling volume on the four strains was detected, and, finally, WXCDD51 was optimal in $50 \mathrm{~mL}$ of culture medium in a $250 \mathrm{~mL}$ shake flask, while $70 \mathrm{~mL}$ was optimal for WXCDD105 and Bs wy-1, and $30 \mathrm{~mL}$ was optimal for Ba (Figure S12).

\subsection{Single and Compound Biocontrol Strains Promote the Growth of Tomato Seeds and Seedlings}

We determined the antimicrobial spectrum of the four strains (Table 1) and tested their compatibility. As it is shown in Figure S13, the strains at the cross-line in the six combinations grew normally. This shows that the four biocontrol bacteria cannot inhibit the growth of each other and can be mixed for subsequent tests. We first observed the effect of single and compound combination bacteria on the germination of tomato seeds. The results show that the four bacteria were effective in promoting seed germination in the order of WXCDD51 > Ba > WXCDD105 > Bs wy-1. After mixed treatment, most of the combinations had no obvious difference from the single strain, and only WXCDD105 + WXCDD51 + Ba showed an obvious effect of promoting seed germination. The germination rate of seeds after 5 days of treatment was $88.00 \%, 12.00 \%$ higher than that of the water control, and $9.00 \%, 2.00 \%, 5.00 \%$ and $11.00 \%$ higher than WXCDD105, WXCDD51, Ba and Bs wy-1, respectively. We named it mixed combination S-1 for follow-up tests (Figure 1). 
Table 1. Fungicide rate of four biocontrol bacteria.

\begin{tabular}{ccccc}
\hline \multirow{2}{*}{ Strain } & \multicolumn{4}{c}{ Fungicide Rate/\% } \\
\cline { 2 - 5 } & WXCDD51 & WXCDD105 & Ba & Bs wy-1 \\
Botrytis cinerea & $85.63 \mathrm{a}$ & $98.61 \mathrm{a}$ & $96.79 \mathrm{a}$ & $98.02 \mathrm{a}$ \\
Corynespora cassiicola & $93.74 \mathrm{a}$ & $93.55 \mathrm{adc}$ & $91.87 \mathrm{~b}$ & $91.80 \mathrm{~cd}$ \\
Fusarium sp. & $56.13 \mathrm{cdef}$ & $96.09 \mathrm{ab}$ & $89.78 \mathrm{bc}$ & $95.45 \mathrm{ab}$ \\
Sclerotinia sclerotiorum (Lib.) de Bary & $69.16 \mathrm{bc}$ & $86.78 \mathrm{def}$ & $83.66 \mathrm{de}$ & $86.93 \mathrm{ef}$ \\
Fusarium oxysporium Schelcht & $58.34 \mathrm{bcdef}$ & $80.05 \mathrm{gh}$ & $85.27 \mathrm{~d}$ & $76.27 \mathrm{~g}$ \\
Pythium sp. & $70.63 \mathrm{~b}$ & $94.57 \mathrm{abc}$ & $95.36 \mathrm{a}$ & $89.61 \mathrm{de}$ \\
Alternaria sp. & $68.31 \mathrm{bcd}$ & $95.35 \mathrm{ab}$ & $94.66 \mathrm{a}$ & $94.98 \mathrm{~b}$ \\
Septoria lycopersici Speg. & $65.79 \mathrm{bcde}$ & $91.54 \mathrm{bcd}$ & $88.36 \mathrm{c}$ & $86.89 \mathrm{ef}$ \\
Colletotrichum lagenarium & $56.97 \mathrm{cdef}$ & $89.44 \mathrm{cde}$ & $80.35 \mathrm{f}$ & $76.38 \mathrm{~g}$ \\
Setosphaeria tuicicum & $53.26 \mathrm{efg}$ & $89.59 \mathrm{cde}$ & $89.99 \mathrm{bc}$ & $88.37 \mathrm{e}$ \\
Fusarium verticillioides & $33.14 \mathrm{~h}$ & $84.76 \mathrm{efg}$ & $80.65 \mathrm{f}$ & $93.94 \mathrm{bc}$ \\
Fusarium oxysporum & $49.61 \mathrm{fg}$ & $73.12 \mathrm{ij}$ & $85.55 \mathrm{~d}$ & $64.57 \mathrm{~h}$ \\
Fusarium oxysporum f. sp. niveum & $55.36 \mathrm{def}$ & $71.73 \mathrm{j}$ & $82.20 \mathrm{ef}$ & $65.84 \mathrm{~h}$ \\
Fusarium bulbigenum var. lycopersici & $51.98 \mathrm{fg}$ & $88.96 \mathrm{cdef}$ & $80.21 \mathrm{f}$ & $85.20 \mathrm{f}$ \\
Fusarium oxysporum f. sp. cucumerinum & $52.01 \mathrm{fg}$ & $83.25 \mathrm{fg}$ & $88.63 \mathrm{c}$ & $87.01 \mathrm{ef}$ \\
\hline
\end{tabular}

Note: Small letters behind the data of the same column indicate significant difference at the 0.05 level. The same as below. Different letters indicate significant differences within each category according to one-way analysis of variance (ANOVA) followed by Duncan's test at the 0.05 alpha level of confidence.

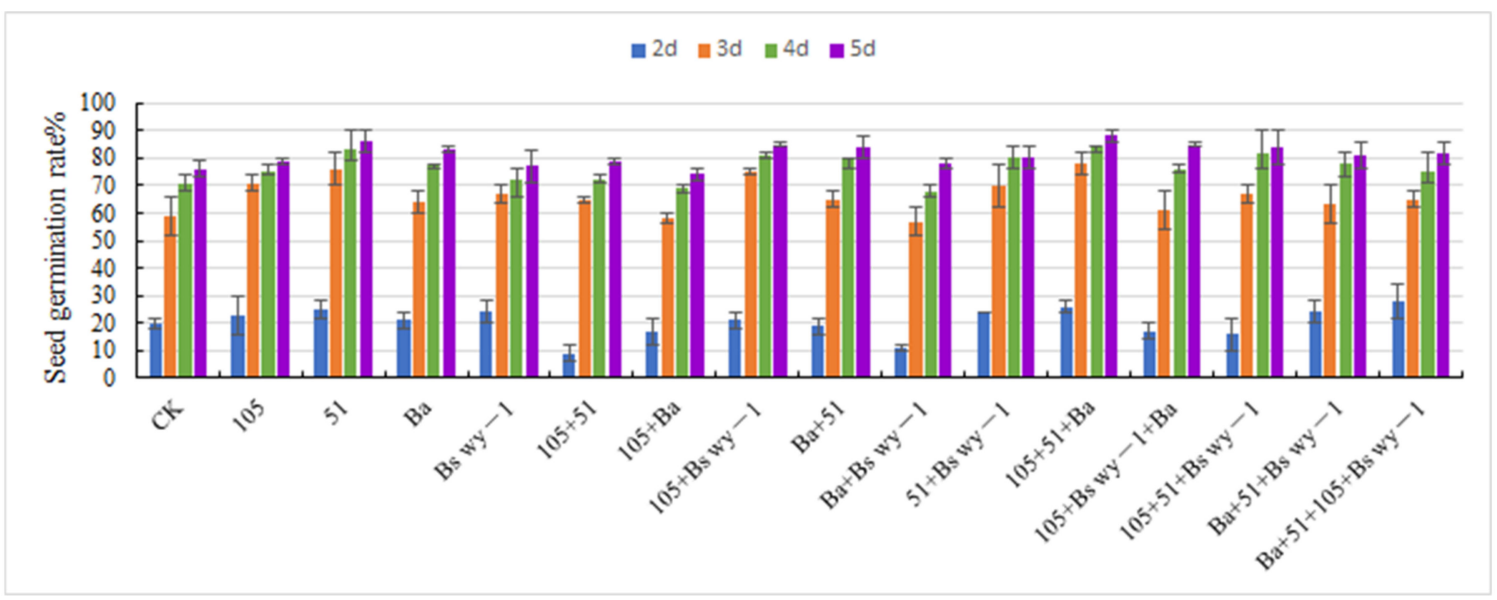

Figure 1. Germination rate of tomato seeds under the treatment of single and compound combined bacterial solutions.

Then, we observed the effect of single and compound combination bacteria on the growth of tomato seed radicles. The results show that the single strains Bs wy- 1 and WXCDD105 had a significant growth-promoting effect on tomato seed radicles. However, the effect of Ba and WXCDD51 with most of the mixed combinations is not obvious. Only Ba + WXCDD51 + Bs wy-1 and Ba + WXCDD51 + WXCDD105 + Bs wy-1 have seed radicle lengths of $41.88 \mathrm{~mm}$ and $46.03 \mathrm{~mm}$, respectively. These are $5.80 \mathrm{~mm}$ and $10.01 \mathrm{~mm}$ longer than the water control group. Among them, the growth-promoting effect of the mixed combination Ba + WXCDD51 + WXCDD105 + Bs wy-1 was significantly higher than that of the single strain treatment group. We named it mixed combination S-2 for follow-up tests (Figure 2). 


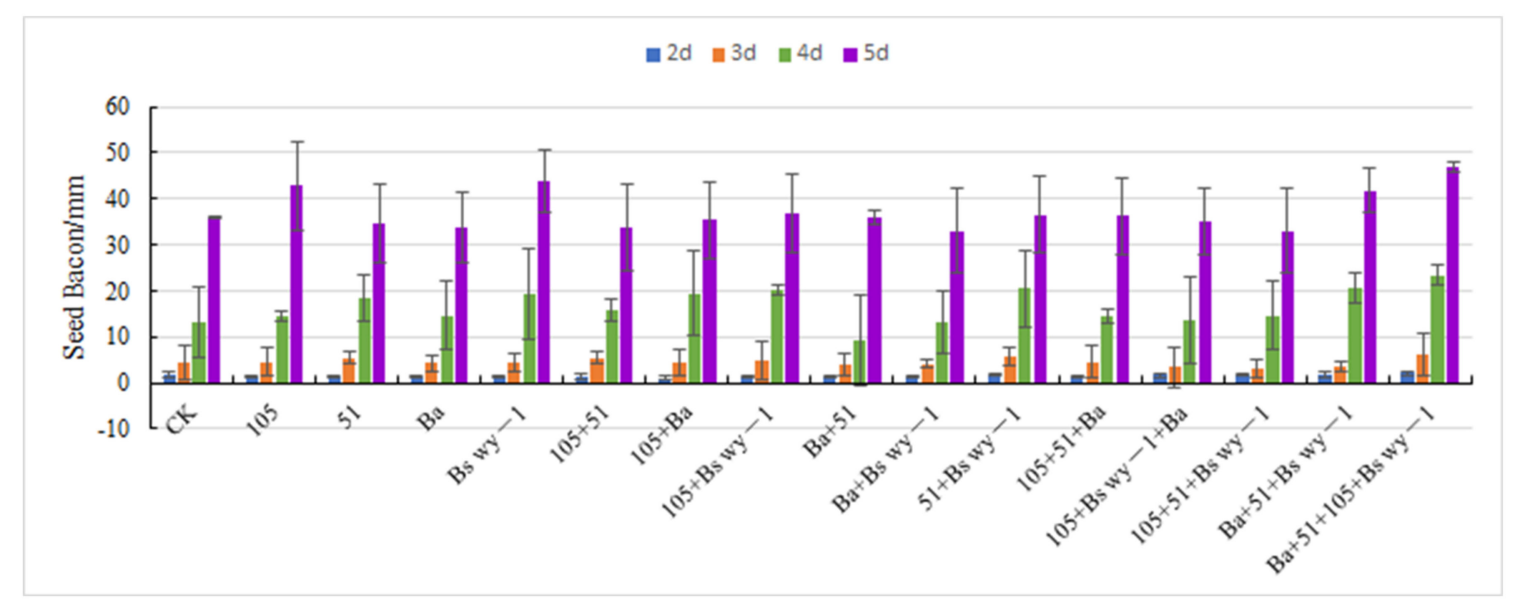

Figure 2. Growth-promoting effect of single and compound combination bacterial liquids on the growth of tomato seed radicles.

The effects of single and compound bacteria on the growth of tomato seedlings were also observed. The results show that different concentrations of the WXCDD51 and WXCDD105 strains had effects on the growth of tomato seedlings at the four-five leaf stage. The effect of the 100-fold dilution is slightly better because the plant height was significantly higher than in the 10-fold dilution, and the growth of tomato seedlings treated in different ways was stronger than the control. For WXCDD51, the effect of soil mixing and seed soaking was better than that of root irrigation, and for WXCDD105, soil mixing was more effective than root irrigation and seed soaking. In contrast, the 10 times dilution of Ba and Bs wy-1 had a better growth effect on the height, stem thickness, main root length and whole plant fresh weight of tomato seedlings than the 100 times dilution. For the Ba bacterial solution, the difference between different treatment methods is not obvious, but for Bs wy-1, soil mixing and root irrigation treatments are slightly more effective than the seed soaking treatment (Figure 3). The mixed combinations of S-1 and S-2 at different concentrations had a positive effect on the growth of tomato seedlings at the four-five leaf stage, and the effect of the 100-fold dilution was relatively good. The growth of tomato seedlings in each treatment was better than that of the control. For the S-1 bacterial solution, the soil mixing and root irrigation treatments were slightly stronger than the seed soaking treatment, and for the S-2 bacterial solution, the seed soaking treatment had a slightly stronger effect (Figure $4 \mathrm{a}, \mathrm{b}$ ). Among them, the indicators of the mixed combination S-2 were higher than those of other treatment groups, and the mixed combination S-1 had no significant difference from the single strains WXCDD51, WXCDD105 and Ba. The single strain Bs wy-1 had the worst relative effect (Figure 4c). 


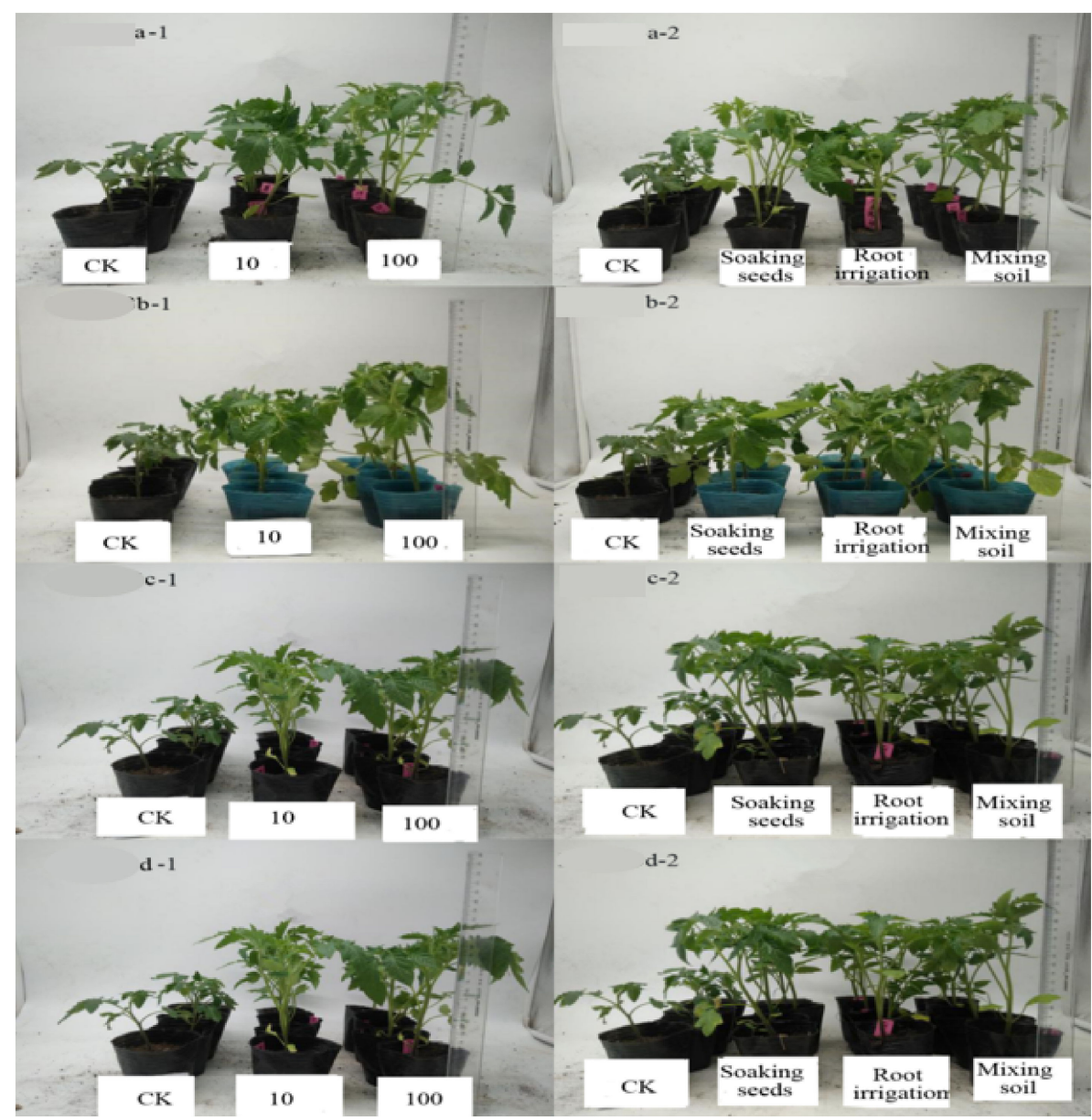

Figure 3. Effects of biocontrol bacteria with different concentrations and treatments on the growth of tomato seedlings. (a) Effects of WXCDD51 fermentation broth on the growth of tomato seedlings with different concentrations (1) and different treatments (2). (b) Effects of WXCDD105 fermentation broth on the growth of tomato seedlings with different concentrations (1) and different treatments (2). (c) Effects of $\mathrm{Ba}$ fermentation broth on the growth of tomato seedlings with different concentrations (1) and different treatments (2). (d) Effects of Bs wy-1 fermentation broth on the growth of tomato seedlings with different concentrations (1) and different treatments (2). 


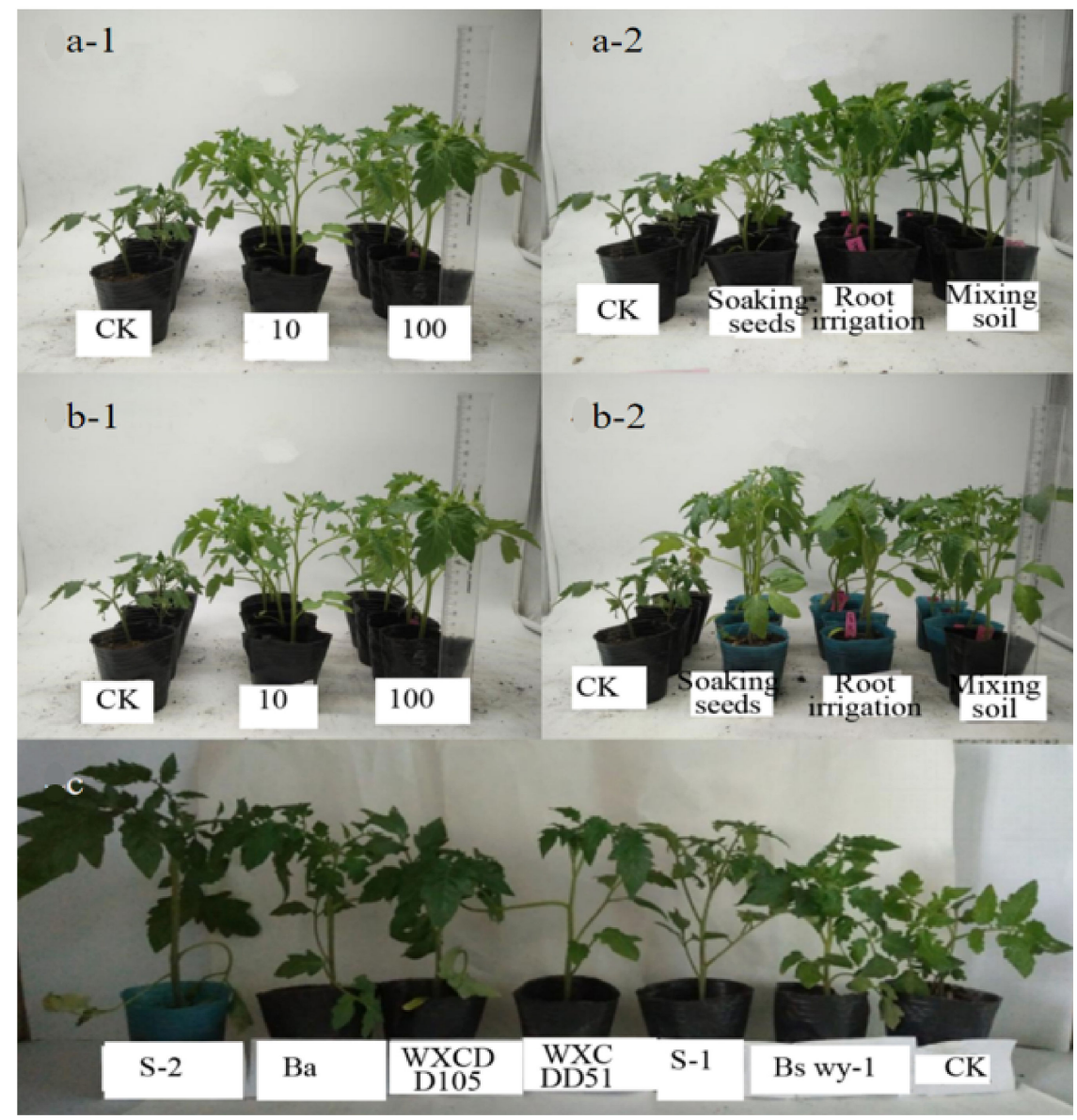

Figure 4. (a) Effects of combination S-1 fermentation broth on the growth of tomato seedlings with different concentrations (1) and different treatments (2). (b) Effects of combination S-2 fermentation broth on the growth of tomato seedlings with different concentrations (1) and different treatments (2). (c) Comparison of effects of single and mixed fermentation broths on the growth of tomato seedlings.

\subsection{Antibacterial Effect of Single and Compound Biocontrol Strains on Tomato Gray Mold and Leaf Mold}

We screened the best compound biocontrol strains and found that the combination of Ba and Bs wy-1 is most effective in inhibiting both gray mold and leaf mold of tomato, followed by the combination of $\mathrm{Ba}+\mathrm{WXCDD105}$. These two combinations were chosen for follow-up tests (Figure S14). The combination of Ba and WXCDD105 had its most effective inhibitory effect on Botrytis cinerea when combined in a ratio of 2:1, having an inhibitory distance and rate of $10.70 \mathrm{~mm}$ and $74.26 \%$, respectively. This combination was named B-1. The effect of the combination of the two bacteria on leaf mold, on the other hand, was most effective at a ratio of 1:4, having an inhibitory distance and rate of $9.25 \mathrm{~mm}$ and $70.63 \%$, respectively. This combination was named F-1 (Table S1).

The combination of Ba and Bs wy-1 in a ratio of 1:3 had the highest inhibitory effect on the growth of Botrytis cinerea, having an inhibitory distance and rate of $10.89 \mathrm{~mm}$ and $74.73 \%$, respectively. This combination was named B-2. The effect of the combination of Ba and Bs wy-1 on leaf mold, on the other hand, was most effective in a ratio of 3:1, having an inhibitory distance and rate of $7.80 \mathrm{~mm}$ and $67.01 \%$, respectively. This combination was named F-2 (Table S2).

In order to more effectively evaluate the effect of biocontrol bacteria on the two diseases, detached tomato fruits and detached leaves were inoculated with Botrytis cinerea and Fulvia fulva, respectively. The control effect of B-1 and B-2 on tomato gray mold infection in vitro was $29.18 \%$ and $32.68 \%$, respectively. The in vitro control effects of single strains WXCDD105, Ba and Bs wy-1 were $15.48 \%, 25.19 \%$ and $11.13 \%$. Thus, the two mixed 
combinations can more effectively control tomato gray mold than any of the bacteria when used as a singleton (Figure 5a). The control effects of the mixed combinations F-2 and F-1 on the detached leaves infected with tomato leaf mold were $82.47 \%$ and $80.51 \%$. The in vitro control effects of single strains WXCDD105, Ba and Bs wy- 1 were $75.37 \%, 79.47 \%$ and $73.02 \%$. This shows that the two mixed combinations can effectively control tomato leaf mold, and the control effect was significantly higher than that of each single strain (Figure 5b).

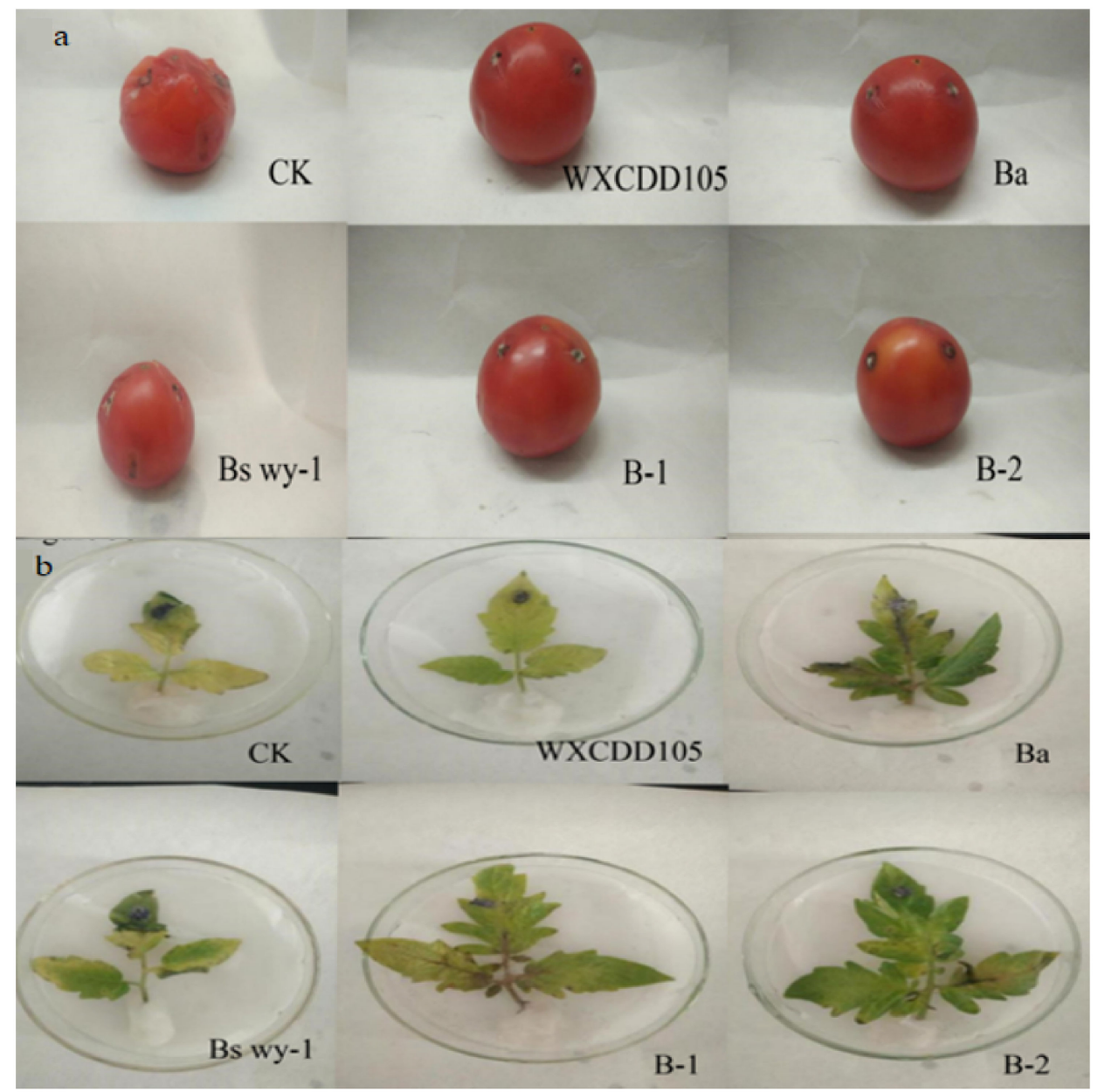

Figure 5. Effects of single and compound strains on the in vitro fruits of tomato gray mold (a) and leaf mold (b).

Pyrimethanil is a chemical agent with a broad bactericidal spectrum and is mainly used to prevent and control gray mold. In the treatment test of tomato gray mold, the incidence and disease index of the chemical pesticide $40 \%$ pyrimethanil treatment were $23.61 \%$ and 16.82 , respectively, and the treatment effect was $61.50 \%$. The morbidity and disease index of the strain combination B-1 were $38.60 \%$ and 10.43 , respectively, which were $19.58 \%$ and $76.12 \%$ less than the water control, and the treatment effect was $76.10 \%$. The morbidity and disease index of the strain combination B-2 were $39.16 \%$ and 12.19 , respectively, which were $18.41 \%$ and $71.54 \%$ less than the water control, and the treatment effect was $72.08 \%$. The treatment effects of the two combinations are stronger than each single strain and chemical pesticides (Figure 6). 


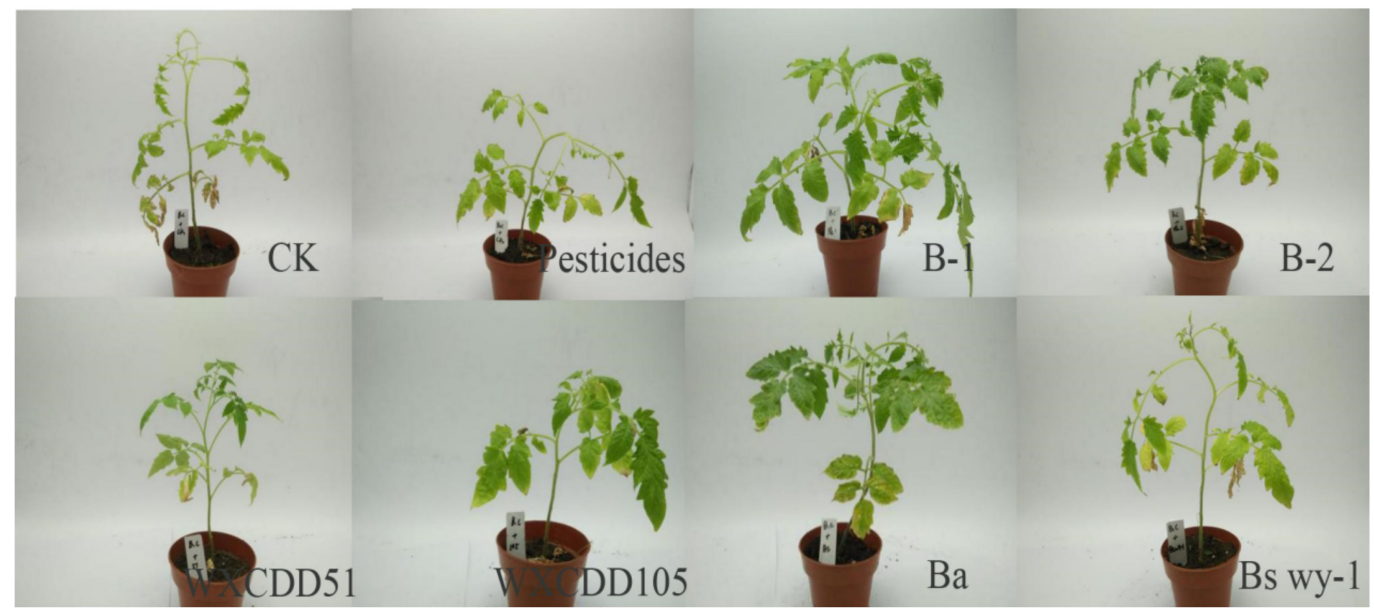

Figure 6. Therapeutic effects of single and complex strains on tomato seedlings infected with gray mold.

Polyoxin is an antibiotic that can effectively prevent leaf mold. In the treatment test of tomato leaf mold, the incidence and disease index of the chemical pesticide $10 \%$ polyoxin treatment were the lowest, $28.22 \%$ and 12.96, respectively, and the curative effect was $71.54 \%$. The morbidity and disease index of the strain combination F-1 were $30.35 \%$ and 9.48 , respectively, which were $37.03 \%$ and $79.22 \%$ less than the water control, and the curative effect was $79.09 \%$. The morbidity and disease index of the strain combination F-2 were $30.21 \%$ and 9.31 , respectively, which were $37.32 \%$ and $79.59 \%$ less than the water control, and the curative effect was $79.56 \%$. Thus, the treatment effects of the two combinations are stronger than each single strain and chemical pesticides (Figure 7).

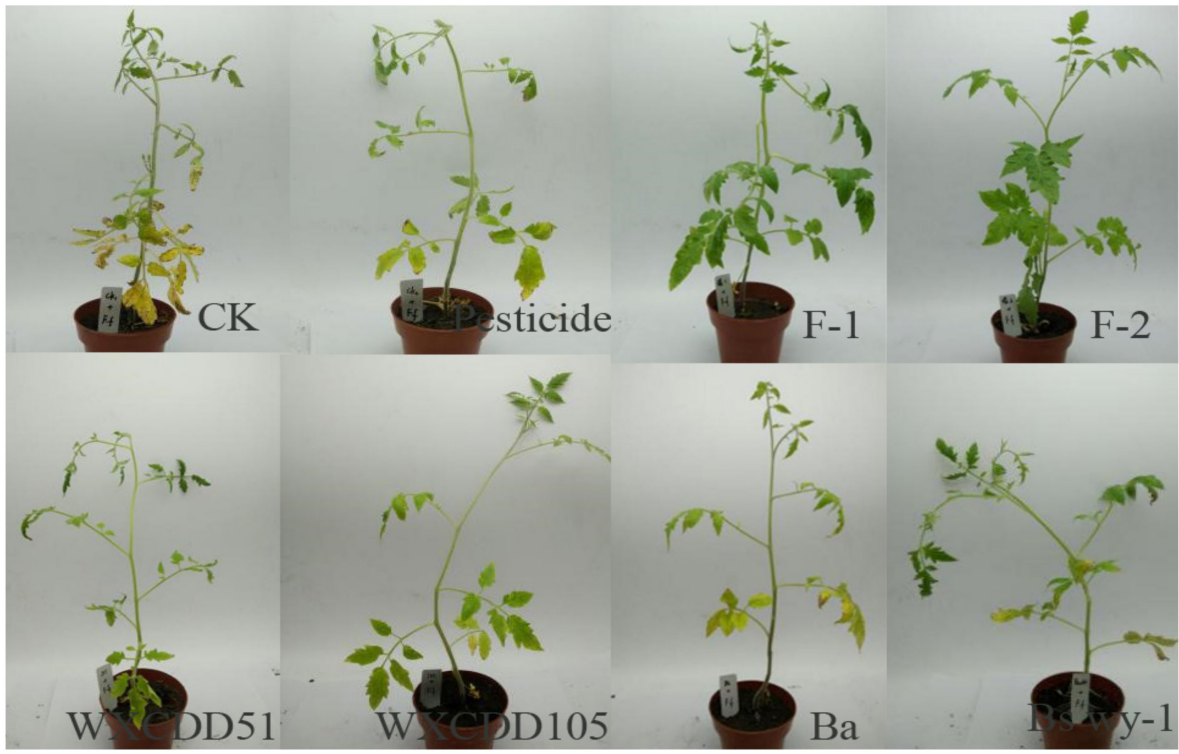

Figure 7. Therapeutic effects of single and complex strains on tomato seedlings infected with leaf mold.

\subsection{Preliminary Study on Antibacterial Substances of Biocontrol Bacteria WXCDD51 and WXCDD105}

Only WXCDD51 had obvious transparent circles around the Oxford cup on the protease-containing identification medium, indicating that WXCDD51 has protease activity, and that no other enzyme activities were detected. In the HCN test, the test paper did not change color, indicating that no HCN was produced (Figure 8a). WXCDD105 had obvious transparent circles around the Oxford cup on the protease- and ferrophilin-containing identification medium, indicating that WXCDD105 can produce protease and ferrophilin, 
and that no other enzyme activities were detected. In the HCN test, the test paper did not change color, indicating that no $\mathrm{HCN}$ was produced (Figure $8 \mathrm{~b}$ ).

The protein substances obtained by the fermentation broth of WXCDD105 and WXCDD51 after $50 \%, 70 \%$ and $90 \%$ of saturation ammonium sulfate precipitation have an inhibitory effect on Botrytis cinerea. This shows that both WXCDD105 and WXCDD51 can produce antibacterial proteins (Figure 8c).

The lipopeptide antibiotics obtained by precipitation of the fermentation broth of WXCDD105 with concentrated hydrochloric acid can inhibit Botrytis cinerea. WXCDD51 did not produce lipopeptide antibiotics (Figure 8d).

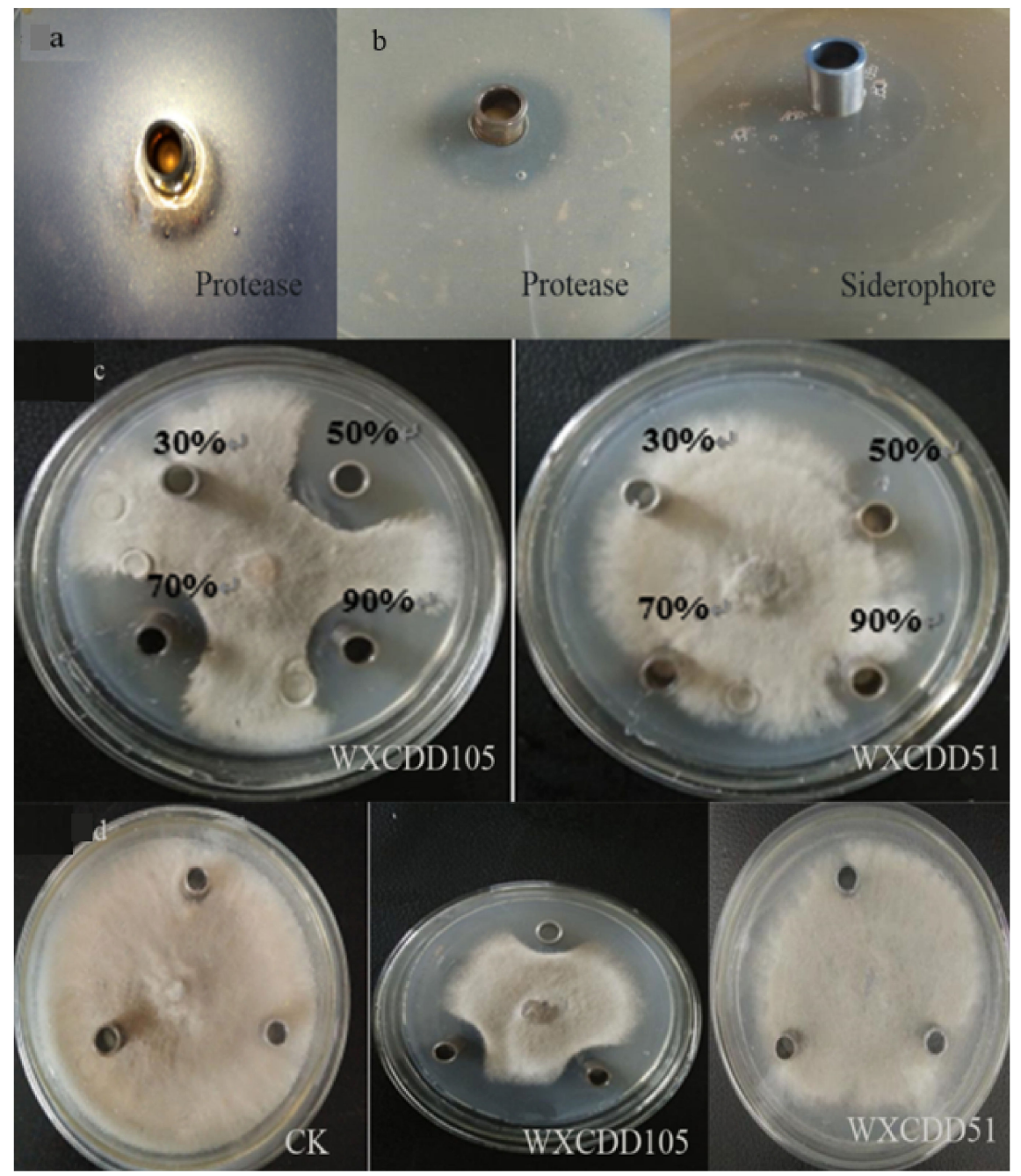

Figure 8. (a,b) Detection of secretory substances in strains WXCDD51 and WXCDD105. (c) Antibacterial activity of antibacterial crude protein. (d) Determination of antibacterial activity of lipopeptide antibiotics.

\section{Discussion}

In this study, the fermentation conditions for four biocontrol bacteria were studied to lay the foundation for the liquid submerged fermentation of the strains. The liquid fermentation process included two aspects: one was the optimization of the medium components, and the other was the optimization of the fermentation conditions. When selecting materials, we considered the growth of bacteria, the production of fermentation products and the cost. A single factor test was used to screen the amount of bacteria and the antibacterial activity of the sterile filtrate as indicators. The carbon source was commonly used sugars and some grain starches as alternative materials. The results show that the best carbon sources for WXCDD51 and Ba are starches, potato starch and soluble 
starch, respectively. The wide source range, low price, large bacterial population and high antibacterial activity of the metabolites made these more advantageous. However, there are also some shortcomings, such as the thicker fermentation broth and being difficult to use. The selected nitrogen sources were organic nitrogen (peptone, beef extract, yeast powder, peanut meal, soybean meal) and inorganic nitrogen (ammonium nitrate, ammonium chloride, urea, potassium nitrate) as alternative materials. The four biocontrol bacteria used organic nitrogen significantly better than inorganic nitrogen. The optimum nitrogen source for WXCDD51 and WXCDD105 was yeast powder [31], and the optimum nitrogen source for Ba and Bs wy-1 was peanut meal powder. Since the source of organic nitrogen is unstable and the composition is more complex, in addition to providing nitrogen, we provided some inorganic salts and growth factors. Subsequent experiments should also consider the impact of raw material fluctuations on fermentation when using organic nitrogen sources. In terms of the selection of inorganic salts, the test was sorted according to the detection index from large to small, and the best inorganic salt combinations for the four biocontrol bacteria were determined.

There have been some reports on some compound strains that promote tomato growth. In this study, four strains of biocontrol bacteria were mixed with one, two, three and four strains and then tested for growth promotion. The results show that all four biocontrol bacteria can promote seed germination. The order of single strains in promoting seed germination is WXCDD51 > Ba > WXCDD105 > Bs wy-1. After the mixed treatment, only the mixed combination S-1 (WXCDD105 + WXCDD51 + Ba) treatment had the highest seed germination rate. Strains Bs wy-1 and WXCDD105 have an obvious promoting effect on seed radicle growth, but $\mathrm{Ba}$ and WXCDD51 have no obvious effect with most mixed combinations. Only S-2 (Ba + WXCDD51 + WXCDD105 + Bs wy-1) has a significantly higher seed radicle length than the single strains. This shows that the growth-promoting effect of different strains on tomato seeds is not necessarily stronger than that of a single strain. This may be related to the mechanism between different biocontrol bacteria and the difference in the production of metabolites. The utilization rate of plants can be improved only by reasonable compounding and increasing the accumulation of nutrients.

This study also explored whether compound strains would have a synergistic effect in promoting growth in tomato seedlings compared with a single strain. First, the optimal concentration and treatment method for growth promotion of each bacterial liquid treatment group were explored. The results show that Ba and Bs wy-1 diluted 100 times have the best effect, and other treatments diluted 10 times have better effects. The single strains adopted the soil mixing treatment to promote the growth effect, and the mixed combinations S-1 and S-2 adopted the root irrigation and seed soaking treatments, respectively. From the comparison of the growth promotion results of the mixed strains and the single strains, the effect of the mixed combination S-2 was significantly stronger than that of other treatment groups. This research also provides a valuable mixed bacteria combination for future production trials, which can be made into different dosage forms, such as powder, granules and seed coatings. This study provides a foundation for the development of a new growth-promoting bioagent.

The antibacterial spectrum test showed that the four biocontrol bacteria have broadspectrum disease resistance, and they are good materials for constructing a combination of compound strains. We also showed that not all combinations can be synergistic, and the number of strains combined does not necessarily make the combination more effective. The mixtures of only two bacteria, such as Ba + Bs wy-1 and Ba + WXCDD105, are more effective in controlling gray mold and leaf mold than any other combinations, including triple combinations. Indeed, there was a major difference between the in vitro activity of biocontrol bacteria and the in vivo control effect. Since it is difficult to evaluate the combination of strains based on the level of the in vitro control effect alone, we conducted a greenhouse pot experiment to further evaluate these effects. The goal of the mixed combination experiments was to obtain a commercial compound bacterial agent that can 
be applied in the field. At present, there are fewer varieties of compound bacteria that can be applied, and the adaptability and spectrum are also poor.

There are not many reports on the mechanism mediating the control of plant diseases by compound bacteria, although studies have shown that interaction between the strains in mixed combinations allows them to have a more significant control effect than single bacteria [32]. The final control effect can also be determined by the affinity between the different strains in the combination. In addition, the interaction between the strains also improves their colonization ability in the rhizosphere of the plant. The complementary effect of the disease prevention mechanism between the strains can also make the disease prevention and growth promotion effects stronger than those of the single strains.

This study determined the antibacterial substances produced by the biocontrol bacteria WXCDD51 and WXCDD105. We found that WXCDD51 can produce proteases, while WXCDD105 can produce both proteases and ferrophils. Research has shown that Bacillus subtilis is able to produce different types of antibacterial substances including larger molecular weight proteins and small-molecular weight lipopeptide antibiotics. Proteins and lipopeptides secreted by Bacillus subtilis STO-12 have been reported to have good antibacterial activity against the pathogens of various fruit tree diseases. Hu et al. used salting-out and acid precipitation methods to prepare crude protein extracts and crude lipopeptide extracts from LB and Landy fermentation broths of endophytic Bacillus subtilis ge25. There are few reports on the production of antibacterial proteins and lipopeptides by Pseudomonas. The antibacterial protein purified from Pseudomonas GY-1 can inhibit wheat root rot. Pseudomonas chlororaphis HT66 can produce the lipopeptide product colistin, which can effectively regulate the relevant biological functions of the strain. In this study, fungicide crude protein was extracted from the fermentation broth of WXCDD51 and WXCDD105, and this inhibited the growth of Botrytis cinerea. A lipopeptide antibiotic with an obvious inhibitory effect on tomato gray mold was extracted from WXCDD105. However, we did not find any lipopeptide antibiotics in the fermentation broth containing WXCDD51. In this study, only the antibacterial substances of two biocontrol bacteria were investigated. The yield of antibacterial substances was also related to the culture conditions of the strain. The disease control mechanism by biocontrol bacteria is extremely complicated. Therefore, in addition to the production of antibacterial substances, various aspects such as competition and induction of the defense response need to be further explored.

\section{Conclusions}

The fermentation medium formulation and fermentation conditions are as follows:

(1) WXCDD51 strain: potato starch $4.97 \%$, yeast extract $1.48 \%$, potassium dihydrogen phosphate $0.06 \%$, disodium hydrogen phosphate $0.15 \%$, sodium chloride $0.3 \%$, magnesium sulfate $0.03 \%$. The initial $\mathrm{pH}$ was 7.0 , the inoculum volume was $2 \%$, the culture temperature was $30^{\circ} \mathrm{C}$ and the liquid volume was $50 \mathrm{~mL} / 250 \mathrm{~mL}$.

(2) WXCDD105 strain: sucrose $4.4 \%$, yeast extract $1.32 \%, 0.08 \%$ calcium chloride, $0.1 \%$ potassium dihydrogen phosphate, $0.02 \%$ manganese sulfate. The initial $\mathrm{pH}$ was $6.5 \%$, the inoculum volume was $2 \%$, the culture temperature was $37^{\circ} \mathrm{C}$ and the liquid volume was $70 \mathrm{~mL} / 250 \mathrm{~mL}$.

(3) Ba strain: soluble starch $4.4 \%$, peanut cake powder $1.31 \%$, disodium hydrogen phosphate $0.04 \%$, calcium chloride $0.3 \%$, potassium dihydrogen phosphate $0.15 \%$. The initial $\mathrm{pH}$ was $6.5 \%$, the inoculum volume was $3 \%$, the culture temperature was $37^{\circ} \mathrm{C}$ and the liquid volume was $30 \mathrm{~mL} / 250 \mathrm{~mL}$.

(4) Bs wy-1 strain: glycerin $2.2 \%$, peanut cake powder $1.24 \%$, calcium chloride $0.09 \%$, potassium dihydrogen phosphate $0.1 \%$, disodium hydrogen phosphate $0.1 \%$. The initial $\mathrm{pH}$ was 7.0 , the inoculation volume was $2 \%$, the culture temperature was $37^{\circ} \mathrm{C}$ and the liquid volume was $70 \mathrm{~mL} / 250 \mathrm{~mL}$.

Antibacterial spectrum tests showed that the four biocontrol bacteria had a broad spectrum of inhibition. The inhibitory rate of strain WXCDD51 against 16 diseases ranged from $33.14 \%$ to $93.74 \%$, that of strain WXCDD105 ranged between $71.73 \%$ and $98.61 \%$, that 
of strain Ba was between $72.28 \%$ and $96.79 \%$ and that of strain Bs wy-1 ranged between $64.57 \%$ and $98.02 \%$.

We studied the effects of single and compound strains on tomato seeds' and seedlings' growth. Screening out the best mixed combinations, S-1 (Ba + WXCDD51 + WXCDD105 + Bs wy-1) and S-2 (Ba + WXCDD51 + WXCDD105 + Bs wy-1), was conducted. The two combinations had the best promoting effects on promoting tomato seeds' germination and tomato seeds' radicle growth, respectively. The seedling stage tests showed that single and mixed combinations of S-1 and S-2 could significantly promote the growth of tomato seedlings. The optimal dilutions of single strains WXCDD51 and WXCDD105 and the combinations of S-1 and S-2 were 100 times dilutions. The optimal dilutions of $\mathrm{Ba}$ and Bs wy-1 were 10 times dilutions (the concentration of the original broth was 108 $\mathrm{cfu} / \mathrm{mL}$ ). The single mixed soil treatment method had the best growth-promoting effects. The combinations of S-1 and S-2 using the root irrigation and seed soaking treatments had the best effects, respectively. Among the single and mixed strains, the combination of S-2 had the best effect on the growth of tomato seedlings, and the single strain Bs wy-1 had the worst effect, but there was a non-significant difference in the other treatments.

We also studied the biocontrol effects of single and combined strains on tomato gray mold and leaf mold. The antagonistic effects of Ba + Bs wy-1 and Ba + WXCDD105 on tomato gray mold and leaf mold were screened. The best compounding ratios of the combinations for the control of gray mold were Ba + WXCDD105 (2:1) and Ba + Bs wy1 (1:3). They were named B-1 and B-2, respectively. The best compounding ratios for controlling leaf mold were Ba + Bs wy-1 (3:1) and Ba + WXCDD105 (1:4). They were named F-1 and F-2, respectively. In the in vitro test, the control effects of combinations B-1 and B-2 on gray mold and combinations of F-1 and F-2 on leaf mold were significantly higher than those of the single strains. In the greenhouse pot experiment, the control effects of each compounding combination on gray mold and leaf mold were also significantly higher than the single strains. The preventive effect of each treatment was better than the treatment effects.

Supplementary Materials: The following are available online at https://www.mdpi.com/article/10 .3390/agriculture11070686/s1, Figure S1: The colony morphology of strain WXCDD51. Figure S2: Phylogenetic tree based on 16S rDNA sequence of strain WXCDD51. Figure S3: The growth curve of four biocontrol bacteria. Figure S4: Linear relationship between bacteria population and absorbance. Figure S5: Effects of different media on growth of the four biocontrol bacteria. Figure S6: Carbon source utilization map of biocontrol bacteria. Figure S7: Nitrogen utilization map of biocontrol bacteria. Figure S8: Application of inorganic salt combinations for biocontrol bacteria. Figure S9: Effects of culture temperature on fermentation of the four biocontrol bacteria. Figure S10: Effects of $\mathrm{pH}$ value on the fermentation of the four biocontrol bacteria. Figure S11: Effects of inoculation amount on fermentation of the four biocontrol bacteria. Figure S12: Effects of liquid loading on fermentation of the four biocontrol bacteria. Figure S13: The growth of cross marking of the four biocontrol bacteria. Figure S14: Inhibitory effects of different treatments on tomato gray mold and leaf mold. Table S1: Screening of different mixing proportions of Ba + WXCDD105. Table S2: Screening of different mixing proportions of $\mathrm{Ba}+\mathrm{Bs} w \mathrm{y}-1$.

Author Contributions: Y.Z. and Y.S. conceived and designed the experiments. X.W. and S.L. were involved in data collection. Y.Z. and X.W. drafted the manuscript. Y.Z. and Y.S. performed the experiments. J.L. and X.C. contributed reagents/materials/analysis tools. A.W. conceived the study and reviewed the manuscript. All authors have read and agreed to the published version of the manuscript.

Funding: This research was supported by the National Key R\&D Program of China (2017YFE0105000), National Natural Science Foundation of China (31872120) and National Natural Science Foundation of China (32002052).

Acknowledgments: We would like to thank the anonymous reviewers for their constructive comments.

Conflicts of Interest: The authors declare no conflict of interest. 


\section{References}

1. Domínguez, I.; Ferreres, F.; del Riquelme, F.P.; Font, R.; Gil, M.I. Influence of preharvest application of fungicides on the postharvest quality of tomato (Solarium L.). Postharvest Biol. Tec. 2012, 72, 1-10. [CrossRef]

2. Zhao, T.T.; Liu, G.; Li, S.; Li, J.; Jiang, J.; Zhang, H.; Kang, L.; Chen, X.; Xu, X. Differentially expressed gene transcripts related to the Cf-19 mediated resistance response to Cladosporium fulvum infection in tomato. Physiol. Mol. Plant Pathol. 2015, 89, 8-15. [CrossRef]

3. Zhu, H.; Huang, C.T.; Ji, M.S. Baseline sensitivity and control efficacy of pyrisoxazole against Botrytis cinerea. Eur. J. Plant Pathol. 2016, 146, 1-9. [CrossRef]

4. Ahmed, F.A.; Sipes, B.S.; Alvarez, A.M. Postharvest diseases of tomato and natural products for disease management. Afr. J. Agric. Res. 2017, 12, 684-691.

5. Xie, C.Q.; Yang, C.; He, Y. Hyperspectral imaging for classification of healthy and gray mold diseased tomato leaves with different infection severities. Comput. Electron. Agric. 2017, 135, 154-162. [CrossRef]

6. Williamson, B.; Tudzynski, B.; Tudzynski, P.; van Kan, J.A. Botrytis cinerea: The cause of grey mould disease. Mol. Plant Pathol. 2007, 8, 561-580. [CrossRef]

7. Chen, C.; Wang, Y.M.; Su, C.; Zhao, X.; Li, M.; Meng, X.; Jin, Y.; Yang, S.H.; Ma, Y.; Wei, D.; et al. Antifungal activity of Streptomyces albidoflavus L131 against the leaf mold pathogen Passalora fulva involves membrane leakage and oxidative damage. Appl. Biol. Chem. 2015, 58, 1-9. [CrossRef]

8. Li, S.; Zhao, T.T.; Li, H.J.; Xu, X.; Li, J. First report of races 2.5 and 2.4 .5 of Cladosporium fulvum (syn. Passalora fulva) causal fungus of tomato leaf mold disease in China. J. Gen. Plant Pathol. 2015, 81, 162-165. [CrossRef]

9. Qiu, D.W. Current status and development strategy for biological control of plant disease in China. Plant Prot. 2010, 36, 15-18.

10. Zhang, C.F.; Chen, K.S.; Wang, G.L. Combination of the biocontrol yeast Cryptococcus laurentii with UV-C treatment for control of postharvest diseases of tomato fruit. BioControl 2013, 58, 269-281. [CrossRef]

11. Wang, J.Y.; Wang, G.P.; Zhang, Y.L.; Zheng, B.; Zhang, C.; Wang, L. Isolation and identification of an endophytic fungus Pezicula sp. in Forsythia viridissima and its secondary metabolites. World J. Microbiol. Biotechnol. 2014, 30, 2639-2644. [CrossRef]

12. You, J.Q.; Zhang, J.; Wu, M.D.; Yang, L.; Chen, W.; Li, G. Multiple criteria-based screening of Trichoderma isolates for biological control of Botrytis cinerea on tomato. Biol. Control 2016, 101, 31-38. [CrossRef]

13. Gao, Z.F.; Zhang, B.J.; Liu, H.P.; Han, J.; Zhang, Y. Identification of endophytic Bacillus velezensis ZSY-1 strain and antifungal activity of its volatile compounds against Alternaria solani and Botrytis cinerea. Biol. Control 2017, 105, 27-39. [CrossRef]

14. Ge, B.B.; Liu, B.H.; Nwet, T.T.; Zhao, W.; Shi, L.; Zhang, K. Bacillus methylotrophicus strain NKG-1, isolated from Changbai mountain, China, has potential applications as a biofertilizer or biocontrol agent. PLoS ONE 2016, 11, e0166079.

15. Jiang, B.B.; Huang, Y.L.; Jia, Z.H.; Song, S.S. Streptomyces nobilis C51 suppresses gray mold caused by Botrytis cinerea in tomato. Br. Microbiol. Res. J. 2016, 16, 1-13. [CrossRef]

16. Kong, H.G.; Chun, O.J.; Choi, K.H.; Lee, K.-Y.; Baek, J.-W.; Kim, H.-J.; Murugaiyan, S.; Moon, B.-J.; Lee, S.-W. Formulation of Bacillus amyloliquefaciens A-2 and its efficacy to control tomato leaf mold disease caused by Fulvia fulva. Adv. Synth. Catal. 2010, $16,837-845$.

17. Zhang, X.H.; Tang, R.; Meng, C.Y. Primary report on the antibacterial material of strain AYM-18 against tomato leaf mould. J. South. Agric. 2014, 45, 1193-1196.

18. Tang, X.J.; He, G.Q.; Chen, Q.H.; Zhang, X.Y.; Ali, M.A. Medium optimization for the pro-duction of thermal stable beta-glucanase by Bacillus subtilis ZJF-1A5 usingresponse surface methodology. Bioresour. Technol. 2004, 93, 175-181. [CrossRef] [PubMed]

19. Dhandhukiap, C.; Thakkarv, R. Response surface methodology to optimize the nutritional parameters for enhanced production of jasmonicacid by Lasiodiplodia theobromae. J. Appl. Microbiol. 2008, 105, 636-643. [CrossRef]

20. Liu, C.; Ruan, H.; Shen, H.; Chen, Q.; Zhou, B.; Li, Y.; He, G. Optimization of the fermentation medium for alpha-galactosidase production from Aspergillus foetidus ZU-G1 using response surface methodology. J. Food Sci. 2007, 72, 120-125. [CrossRef]

21. Saudagarp, S.; Singhalr, S. Optimization of nutritional requirements and feeding strategies for clavulanic acid production by Streptomyces clavuligerus. Bioresour. Technol. 2007, 98, 2010-2017. [CrossRef]

22. Roberts, D.P.; Lohrke, S.M.; Meyer, S.L.; Buyer, J.S.; Bowers, J.H.; Baker, C.J.; Li, W.; de Souza, J.T.; Lewis, J.A.; Chung, S. Biocontrol agents applied individually and in combination for suppression of soil borne diseases of cucumber. Crop. Prot. 2005, 24, 141-155. [CrossRef]

23. Saldajeno MG, B.; Chandanie, W.A.; Kubota, M.; Hyakumachi, M. Effects of interactions of arbuscular mycorrhizal fungi and beneficial saprophytic mycoflora on plant growth and disease protection. In Myorrhizae: Sustainable Agriculture and Forestry; Siddiqui, Z.A., Akhtar, M.S., Futai, K., Eds.; Springer Sciences: Dordrecht, The Netherlands, 2008; pp. 211-226.

24. Barea, J.M.; Azcon-Aguilar, C.; Azcon, R. Interactions between Mycorrhizal Fungi and Rhizosphere Microorganisms within the Context of Sustainable Soil-Plant Systems; Blackwell Science Ltd.: Hoboken, NJ, USA, 1997.

25. Martinez-Medina, A.; Pascual, J.A.; Lloret, E.; Roldan, A. Interactions between arbuscular mycorrhizal fungi and Trichoderma harziahum and their effects on Fusarium wilt in melon plants grown in seedlings nurseries. J. Sci. Food Agric. 2009, 89, 1843-1850. [CrossRef]

26. Okami, Y.; Okazaki, T.; Kitahara, T.; Umezawa, H. Studies on marine microorganisms. V. A new antibiotic, aplasmomycin, produced by a streptomycete isolated from shallow sea mud. J. Antibiot. 1976, 9, 1019-1025. [CrossRef] 
27. Burgess, J.G.; Jordan, E.M.; Bregu, M.; Mearns-Spragg, A.; Boyd, K.G. Microbialantagonism: A neglected avenue of natural products research. J. Biotechnol. 1999, 70, 27-32. [CrossRef]

28. Hopwood, D.A.; Chater, K.F. Fresh approaches to antibiotic production. Philos. Trans. R. Soc. Lond. B Biol. Sci. 1980, 90, 313-328.

29. Wang, H.; Shi, Y.; Wang, D.; Yao, Z.; Wang, Y.; Liu, J.; Zhang, S.; Wang, A. A biocontrol strain of Bacillus subtilis WXCDD105 used to control tomato Botrytis cinerea and Cladosporium fulvum Cooke and promote the growth of seedlings. Int. J. Mol. Sci. 2018, 19, 1371. [CrossRef]

30. Tian, Y.; Fan, Y.; Zhao, X.; Zhang, J.; Yang, L.; Liu, J. Optimization of fermentation medium for acetoin production by Bacillus subtilis SF4-3 using statistical methods. Prep. Biochem. Biotechnol. 2014, 44, 529-543. [CrossRef]

31. Liu, K.; McInroy, J.A.; Hu, C.H.; Kloepper, J.W. Mixtures of Plant-Growth-Promoting Rhizobacteria Enhance Biological Control of Multiple Plant Diseases and Plant-Growth Promotion in the Presence of Pathogens. Plant Dis. 2018, 102, 67-72. [CrossRef]

32. Yu, Y.Y.; Xu, J.D.; Huang, T.X.; Zhong, J.; Yu, H.; Qiu, J.P.; Guo, J.H. Combination of beneficial bacteria improves blueberry production and soil quality. Food Sci. Nutr. 2020, 8, 5776-5784. [CrossRef] [PubMed] 